e-ISSN : 2621-4105

\title{
KEWAJIBAN PELAPORAN HARTA KEKAYAAN BAGI PENYELENGGARA NEGARA
}

\author{
Dwi Harmono, Kadi Sukarna, Diah Sulistyani, Muhammad Junaidi \\ Magister Hukum Universitas Semarang \\ zaenal@usm.ac.id
}

\begin{abstract}
Abstrak
Tujuan penelitian ini adalah untuk mengkaji dan menganalisis kewajiban pelaporan harta kekayaan bagi pejabat negara dan kendala serta solusi pemerintah terhadap permasalahan yang timbul dalam kewajiban pelaporan harta kekayaan bagi pejabat negara. Adanya Undang-Undang Pemberantasan Tindak Pidana Korupsi (UU PTPK) menjadi harapan bagi bangsa Indonesia dalam memberantas korupsi, namun, pemberantasan kasus korupsi tetap mengalami kesulitan, langkah-langkah pemberantasannya masih tersendat-sendat sampai sekarang. Korupsi sudah merupakan penyakit yang telah kronis menjangkiti dan belum dapat disembuhkan hingga saat ini yang menyebar ke seluruh sektor pemerintah bahkan sampai ke perusahaan-perusahaan milik negara. Oleh sebab itu, guna meminimalisir pejabat yang korupsi serta timbulnya kerugian negara akibat oknum-oknum yang koruptif, maka setiap pejabat negara wajib melaporkan kekayaannya. Hasil penelitian ini adalah: Pelaporan harta kekayaan pejabat negara saat ini sudah terintegrasi dalam sebuah Program e-LHKPN atau Laporan Harta Kekayaan berbasis elektronik. Kendala yang dihadapi terkait pelaporan harta kekayaan oleh pejabat negara meliputi kurangnya sosialisasi ke instansi-instansi. Solusinya adalah berdasarkan penelitian, fasilitas atau sumberdaya-sumberdaya tersebut sudah cukup terpenuhi, namun berdasarkan hasil observasi yang dilakukan peneliti, perlu adanya sosialisasi secara terstruktur dan kontinyu.
\end{abstract}

Kata Kunci : Pelaporan; Harta Kekayaan; Penyelenggara Negara 
e-ISSN : 2621-4105

\title{
OBLIGATION TO REPORT THE ASSETS OF STATE OFFICIALS
}

\begin{abstract}
The purpose of this research is to study and analyze the obligation to report assets for state officials and the constraints and solutions of the government to problems that arise in the obligation to report assets for state officials. The Law of Corruption Eradication Act (the PTPK ACT) became a hope for the Indonesian people to eradicate corruption, but the eradication of corruption has remained difficult, eradication measures are still intermittently Until now. Corruption is already a chronic disease that has been infected and has not been healed until now that spreads to all sectors of the government even to state-owned companies. Therefore, to minimize the corruption officials and the incidence of state losses due to the corruptive persons, then every state official is obliged to report its wealth. The problem in this study is a) how is property reporting obligation for State officials? b) How are the constraints and wealth reporting solutions for state officials? The method in this study uses a qualitative descriptive research method with a normative juridical approach. The results of this research are (1) the state Office's wealth reporting is already integrated in an e-LHKPN Program or the electronic asset-based property report (2) Constraints faced with the reporting of assets by state officials include the lack of socialization to agencies. Besides that, all officials are required to report their assets regularly. The solution is based on research, the facilities or resources are sufficiently fulfilled, but based on the results of observations made by researchers, it is necessary to have structured and continuous socialization.
\end{abstract}

Keywords : Report; Wealth; State Officials 
e-ISSN : 2621-4105

\section{A. PENDAHULUAN}

Indonesia adalah negara yang berdasarkan atas hukum, yang bermakna bahwa Negara Indonesia adalah Negara hukum sebagaimana termaktub di dalam Undang-Undang Dasar Negara Republik Indonesia (UUD NRI) Tahun 1945. ${ }^{1}$ Tujuan pembangunan nasional adalah mewujudkan manusia Indonesia seutuhnya dan masyarakat yang adil, Makmur, sejahtera, dan tertib berdasarkan Pancasila dan Undang-Undang Dasar 1945. Untuk mewujudkan masyarakat Indonesia yang adil, Makmur, dan sejahtera tersebut, perlu ditingkatkan secara terus menerus usaha-usaha pencegahan pelanggaran hukum. ${ }^{2}$ Hukum memiliki arti penting dalam setiap aspek kehidupan, pedoman tingkah laku manusia dalam hubungannya dengan manusia yang lain, dan hukum yang mengatur segala kehidupan masyarakat Indonesia.

Setiap tindakan warga negara diatur dengan hukum, setiap aspek memiliki aturan, ketentuan dan peraturannya masing-masing. Hukum menetapkan apa yang harus dilakukan, apa yang boleh dilakukan serta apa yang dilarang. Salah satu bidang dalam hukum adalah hukum pidana yaitu mengatur tentang aturan perbuatan-perbuatan tertentu yang dilarang. Sedangkan tindak pidana, merupakan perbuatan yang dilarang oleh suatu aturan hukum yang mana disertai ancaman (sanksi).

Pasal 2 ayat (1) Undang-Undang Nomor 31 Tahun 1999 jo. UU Nomor 20 tahun 2001 menjelaskan bahwa setiap orang yang secara melawan hukum melakukan perbuatan memperkaya diri sendiri atau orang lain atau suatu korporasi yang dapat merugikan keuangan negara atau perekonomian negara. Selanjutnya pada Pasal 3 Undang-Undang Nomor 31 Tahun 1999 jo. UndangUndang Nomor 20 Tahun 2001 juga menjelaskan tentang perilaku koruptif melalui penyalahgunaan wewenang.

Penelitian ini terkait dengan penelitian Yuniarty Veronika Ingnuan dan Mohamad Lutfi (2018), penelitian ini lebih fokus menguji dan menganalisa

${ }^{1}$ Pasal 1 ayat 3 Undang-Undang Dasar Negara Republik Indonesia Tahun 1945

${ }^{2}$ Aryas Adi Suyanto, "Komisi Pemberantasan Korupsi Sebagai Lembaga Rasuah dalam Pemberantasan Tindak Pidana Korupsi di Indonesia", Jurnal USM Law Review 1 (1), 2018, hal 39. DOI: 10.24914/jeb.v2li2.1985 
pelaksanaan peningkatan kepatuhan pelaporan Laporan Harta Kekayaan Penyelenggara Negara (LHKPN) di lingkup instansi daerah pada Direktorat Pendaftaran dan Pemeriksaan LHKPN. Hasil dari penelitian tersebut menyatakan bahwa tingkat Kepatuhan Pelaporan LHKPN di lingkup instansi daerah mengalami penurunan dari tahun 2016-2017. Prosentase tersebut masih bisa naik apabila didukung dengan adanya peran serta kesadaran wajib lapor untuk melaporkan harta kekayaannya dan komitmen Kepala Daerah/ Pimpinan Instansi terkait penerapan sanksi bagi wajib lapor yang tidak melaporkan LHKPN pada KPK. Selanjutnya tingkat Kepatuhan Pelaporan LHKPN di Lingkup Pemerintah Provinsi Kepulauan Bangka Belitung pada tahun 2017 mengalami kenaikan. Fokus penelitian hanya di Kepatuhan Pelaporan LHKPN di lingkup instansi daerah dan di lingkup Pemerintah Provinsi Kepulauan Bangka Belitung. ${ }^{3}$

Sedangkan penelitian dari Wilson Gunawan Salim (2020) yang berjudul Kepastian Hukum Terhadap Tidak Di Laporkan Harta Kekayaan Penyelenggara Negara Dalam Penyeleksian Calon Pimpinan Komisi Pemberantasan Korupsi mengangkat permasalahan tentang bagaimana akibat jika tidak dipertimbangkannya LHKPN (Laporan Harta Kekayaan Penyelenggara Negara) oleh panitia seleksi calon pimpinan KPK ditinjau dari Pasal 29 Undang-Undang Nomor 30 Tahun 2002 tentang Komisi Pemberantasan Tindak Pidana Korupsi Jo. Pasal 5 Undang-Undang Nomor 28 Tahun 1999 tentang Penyelenggaraan Negara Yang Bersih Dan Bebas Dari Korupsi, Kolusi, Dan Nepotisme berkaitan dalam mengumumkan harta kekayaan calon pimpinan KPK? Penelitian tersebut lebih fokus mengkaji tentang tidak dipertimbangkannya LHKPN (Laporan Harta Kekayaan Penyelenggara Negara) oleh panitia seleksi calon pimpinan KPK. ${ }^{4}$

\footnotetext{
${ }^{3}$ Yuniarty Veronika Ingnuan, Mohamad Lutfi, Pelaksanaan Peningkatan Kepatuhan Pelaporan Laporan Harta Kekayaan Penyelenggara Negara (LHKPN), Jurnal EKOBIS 8 (2), 2018. DOI : $10.37932 /$ j.e.v8i2.43

${ }^{4}$ Wilson Gunawan Salim, Kepastian Hukum Terhadap Tidak Di Laporkan Harta Kekayaan Penyelenggara Negara Dalam Penyeleksian Calon Pimpinan Komisi Pemberantasan Korupsi, Jurnal Corruptio 1 (1), 2020. https://doi.org/10.25041/corruptio.v1i1.2074
} 
Adanya Undang-Undang Pemberantasan Tindak Pidana Korupsi (UU PTPK) menjadi harapan bagi bangsa Indonesia dalam memberantas korupsi, namun, pemberantasan kasus korupsi tetap mengalami kesulitan, langkahlangkah pemberantasannya masih tersendat-sendat sampai sekarang. Korupsi sudah merupakan penyakit yang telah kronis menjangkiti dan belum dapat disembuhkan hingga saat ini yang menyebar ke seluruh sektor pemerintah bahkan sampai ke perusahaan-perusahaan milik negara. Oleh sebab itu, guna meminimalisir pejabat yang korupsi serta timbulnya kerugian negara akibat oknum-oknum yang koruptif, maka setiap pejabat negara wajib melaporkan kekayaannya.

Selain itu, undang-undang tersebut hanya memberikan sanksi bagi yang tidak taat dalam pelaporan harta kekayaannya, padahal tidak menutup kemungkinan, Wajib LHKPN tersebut sengaja salah melaporkan harta kekayaannya. Pejabat negara lain yang sudah melepaskan masa jabatannya, juga sulit dikenakan sanksi administrasi lagi bila setelah menjabat tidak melaporkan LHKPN. Khususnya karena yang bersangkutan statusnya bukan penyelenggara lagi dan tidak terikat dengan sanksi administratif. Peraturan tersebut merupakan sebuah bentuk komitmen pemberantasan korupsi dalam organisasi pemerintahan termasuk pemantauan pada setiap kode etik serta kebijakan-kebijakan seputar keuangan oleh pejabat negara. ${ }^{5}$

Namun hal tersebut memunculkan kekhawatiran atas problematika hukum baru. Dalam implementasinya, dikhawatirkan harta yang diungkap ternyata diperoleh dari serangkaian kegiatan yang merupakan sebuah tindak pidana di Indonesia. Contohnya harta yang diperoleh melalui tindak pidana korupsi, atau harta yang dikelola dengan metode pencucian uang. Peluang tersebut jelas saja menjadi kesempatan bagi para pelaku tindak pidana di bidang keuangan untuk dapat menyelamatkan harta di bidang keuangan untuk

${ }^{5}$ Anton Wibisono, "Determinan Intensi Pelaporan Pelanggaran: Studi Empiris Pada Direktorat Jenderal Kekayaan Negara", Jurnal Ekonomi dan Bisnis, 21(2), 2018, hal 204, DOI: $10.24914 /$ jeb.v2li2.1985. 
dapat menyelamatkan harta yang telah diperoleh agar terlindungi ketika harta tersebut hendak dimasukkan ke dalam Indonesia. ${ }^{6}$

Penelitian ini berbeda dengan penelitian sebelumnya oleh Yuniarty Veronika Ingnuan dan Mohamad Lutfi (2018) yang hanya fokus meneliti Kepatuhan Pelaporan LHKPN di lingkup instansi daerah dan di lingkup Pemerintah Provinsi Kepulauan Bangka Belitung. Sedangkan penelitian serupa oleh Wilson Gunawan Salim (2020) lebih fokus mengkaji tentang tidak dipertimbangkannya LHKPN (Laporan Harta Kekayaan Penyelenggara Negara) oleh panitia seleksi calon pimpinan KPK. Ruang lingkup penelitian ini lebih luas dengan mengakji mengenai bagaimana pelaksanaan kewajiban pelaporan harata kekayaan peneyelenggara negara. Tujuan dari penelitian ini adalah untuk mengkaji dan menganalisis kewajiban pelaporan harta kekayaan bagi pejabat negara dan kendala serta solusi pemerintah terhadap permasalahan yang timbul dalam kewajiban pelaporan harta kekayaan bagi pejabat negara.

\section{B. PERMASALAHAN}

Berdasarkan latar belakang diatas, maka penulis dapat merumuskan masalah yang akan menjadi acuan dalam penelitian ini yaitu : (1) Bagaimana kewajiban pelaporan harta kekayaan bagi pejabat negara? (2) Bagaimana kendala dan solusi terhadap permasalahan yang timbul dalam kewajiban pelaporan harta kekayaan bagi pejabat negara?

\section{METODE PENELITIAN}

Penelitian (research) merupakan upaya pencarian yang bernilai edukatif. Dengan demikian penelitian berangkat dari ketidaktahuan dan keraguan dan kemudian berakhir pada suatu kesimpulan dari permasalahan. ${ }^{7}$ Pada penelitian ini metode yang digunakan tidak mendasar angka-angka statistik tetapi terlebih pada pemahaman dan deskripsi secara normatif. Dengan demikian metode pendekatan yang digunakan dalam penelitian ini adalah metode kualitatif.

${ }^{6}$ Ahmaf Fajri Kahar, "Pengampunan Pajak Terhadap Harta Kekayaan Hasil Tindak Pidana Pencucian Uang", Jurnal Education and Development Institut Pendidikan Tapanuli Selatan 8 (2), 2020, hal 185, DOI: 10.37081/ed.v812.

${ }^{7}$ Amirudin, Pengantur Metode Penelitian Hukum, PT. Raja Grafindo Persada, Jakarta, 2004, hlm. 19. 
Penelitian ini dilakukan dengan meneliti data yang diperoleh dari penelitian lapangan dan bahan-bahan kepustakaan yang berhubungan dengan perumusan masalah yang telah ditetapkan. Penelitian hukum normatif setalu mengambil isu dari hukum sebagai sebagai norma yang digunakan untuk memberikan "justifikasi" perspesktif tentang suatu hukum. ${ }^{8}$ Penelitian ini dikategorikan sebagai penelitian normatif karena meneliti bahan pustaka terhadap data sekunder yang bersumber pada bahan kepustakaan yang berkaitan dengan pemenuhan pelaporan harta kekayaan pejabat negara. Spesifikasi penelitian ini adalah deskriptif analitis. Penelitian ini berusaha menggambarkan dan menganalisis permasalahan berdasarkan peraturan perundang-undangan yang berlaku. Dalam penelitian ini penulis ingin menggambarkan dan menganalisis mengenai pemenuhan pelaporan harta kekayaan pejabat negara. Sehubungan dengan metode pendekatan dalam penelitian ini adalah yuridis normatif, maka penelitian ini dilakukan dengan studi pustaka yang bersumber pada data sekunder. Bahan Hukum Sekunder yaitu bahan-bahan yang erat hubungannya dengan bahan-bahan hukum primer yang dapat menunjang penulisan tesis ini. Bahan hukum sekunder yang digunakan adalah buku-buku atau karya ilmiah yang ditulis oleh para ahli yang berkaitan dengan penelitian ini. Dalam penelitian ini, penulis menggunakan bahan hukum sekunder yaitu artikel, paper, hasil penelitian, dan buku-buku yang berkaitan dengan pemenuhan pelaporan harta kekayaan pejabat negara. Data sekunder yang merupakan sumber utama dalam penelitian ini dikumpulkan dengan melakukan studi kepustakaan/studi pusat dokumen. Data sekunder diperoleh di perpustakaan, pusat dokumentasi, arsip dan museum. ${ }^{9}$ Dengan demikian studi ini untuk mencari konsepsi-konsepsi, teori-teori, pendapat-pendapat dan penemuanpenemuan yang berhubungan dengan pokok permasalahan. ${ }^{10}$ Yakni tentang pemenuhan pelaporan harta kekayaan pejabat negara. Penelitian ini bersifat

\footnotetext{
${ }^{8}$ Mukti Fajar ND dan Yulianto Achmad, Dualisme Penelitian Hukum Normatif \& Empihs, Pustaka Pelajar, Yogyakarta, 2013, hlm. 34.

${ }^{9}$ Burhan Ashofa, Metode Penelitian Hukum. Rineka Cipta, Jakarta, hlm. 104.

${ }^{10}$ Rony Hanitijo Soemitro. Metode Penelitian Hukum dan Jumitri. Ghalia Indonesia, Yogyakarta, hlm. 98.
} 
analitis kualitatif, yaitu menggambarkan, menjelaskan, serta menganalisis sejumlah data sekunder yang telah diperoleh. Penjelasan terhadap data dilakukan dengan menggunakan teori-teori dan norma-norma hukum yang ada sedangkan keseluruhan data yang diperoleh disajikan secara kualitatif yaitu dalam bentuk uraian yang sistematis. ${ }^{11}$

\section{PEMBAHASAN}

\section{Kewajiban Pelaporan Harta Kekayaan Bagi Pejabat Negara}

Kecurangan atau korupsi adalah cara kecerdikan yang digunakan oleh seseorang untuk memperoleh keuntungan dari orang lain melalui perbuatan yang tidak benar. Kecurangan atau korupsi dapat muncul dalam bentuk kegiatan manipulasi keuangan yang dilakukan oleh pihak eksekutif maupun pihak lain, baik di organisasi publik maupun swasta. ${ }^{12}$ Harta kekayaan yang harus dilaporkan adalah harta benda berupa benda bergerak, berwujud atau tidak berwujud, termasuk hak dan kewajiban lainnya yang dapat dinilai dengan uang yang dimiliki oleh penyelenggara negara beserta isteri/suami dan anak yang masih dalam tanggungan penyelenggara negara, bai katas nama penyelenggara negara atau orang lain yang diperoleh sebelum dan selama penyelenggara negara memangku jabatannya. ${ }^{13}$

Pelaporan harta kekayaan bagi pejabat negara merupakan suatu kewajiban. Hal ini jelas sudah tercantum dalam Surat Edaran Menteri Dalam Negeri. Berdasarkan Surat Edaran Menteri Dalam Negeri Nomor 700/6597/SJ Tertanggal 17 November 2014 Tentang Kewajiban Penyampaian Laporan Harta Kekayaan Penyelenggara Negara (LHKPN) Di Lingkungan Kementrian Dalam Negeri Dan Pemerintah Daerah, bahwa dalam rangka pelaksanaan upaya pencegahan dan pemberantasan korupsi melalui penyampaian Laporan Harta Kekayaan Penyelenggara Negara

${ }^{11}$ Soerjono Soekanto, Op. Cit, hlm. 25.

${ }^{12}$ Heri Fasial Harahap, "Pengaruh Jalur Pelaporan dan Komitmen Religius Terhadap Niat Melakukan Whistleblowing: Sebuah Studi Eksperimen", JIA (Jurnal Ilmiah Akuntansi, 5(1), 2020, hal 131. DOI: 1023887/jia.v5il.24289.

${ }^{13}$ Zainal Putra, "Sosialisasi Pelaporan Harta Kekayaan Penyelenggara Negara dengan Sistem E-LHKPN di Lingkungan Universitas Teuku Umar", Jurnal Adimas 4 (1), 2020, hal 30. DOI: 10.24269 /adi.v4il.2301. 
sebagaimana diwajibkan berdasarkan Undang-Undang Nomor 28 Tahun 1999 tentang Penyelenggaraan Negara yang Bebas dari Korupsi, Kolusi, dan Nepotisme, Undang-Undang Nomor 30 Tahun 2002 tentang Komisi Pemberantasan Korupsi dan instruksi Presiden Nomor 5 Tahun 2004 tentang Percepatan Pemberantasan Korupsi.

Sebagaimana tertulis dalam Undang - Undang Nomor 28 Tahun 1999 tentang Penyelenggara Negara yang bersih dan bebas dari Korupsi, Kolusi dan Nepotisme dan Undang - Undang Nomor 30 tahun 2002 tentang Komisi Pemberantasan Korupsi, maka para penyelenggara negara memiliki kewajiban untuk memberikan laporan harta kekayaannya sebelum dan sesudah menjabat di satu posisi jabatan tertentu, yaitu sebagai penyelenggara negara.

Tujuan dari pembuatan Laporan Harta Kekayaan Penyelenggara Negara (LHKPN) adalah sebagai bagian dari wewenang yang dimiliki Komisi Pemberantasan Korupsi yaitu melaksanakan langkah atau upaya pencegahan terjadinya tindak pidana korupsi atara lain dengan melakukan pendaftaran dan pemeriksaan terhadap Laporan Harta Kekayaan Penyelenggara Negara (LHKPN).

Pemeriksaan itu sendiri disampaikan kepada Komisi Pemberatasan Korupsi dengan tujuan untuk mewujudkan penyelenggara negara yang mentaati asas-asas umum penyelenggara negara yang terbebas dari praktek Korupsi, Kolusi, Nepotisme serta perbuatan tercela lainnya.

Komisi Pemberatasan Korupsi, dalam hal ini Direkturat Laporan Harta Kekayaan Penyelenggara Negara (LHKPN) mempunyai kewajiban untuk memberikan jaminan atas kerahasian dan penggunaan Laporan Harta Kekayaan Penyelenggara Negara (LHKPN) sesuai aturan hukum dan undang-undang. Hal tersebut sebagai bagian penghargaan Komisi Pemberantasan Korupsi kepada penyelenggara negara yang secara sadar dan sukarela memberikan laporan hartanya kepada Komisi Pemberantasn Korupsi melalui formulir Laporan Harta Kekayaan Penyelenggara Negara (LHKPN). Hal ini tercantum dalam tugas pokok dan kewenangan Komisi 
Pemberantasan Korupsi sesuai Pasal 6 dan Pasal 7 Undang - Undang Komisi Pemberatasn Korupsi:

1. Melakukan koordinasi dengan instansi yang berwenang melakukan pemberantasan tindak pidana korupsi;

2. Melakukan supervisi terhadap instansi yang berwenang melakukan pemberantasan tindak pidana korupsi;

3. Melakukan penyelidikan, penyidikan, dan penuntutan terhadap tindak pidana;

4. Melakukan tindakan tindakan pencegahan tindak pidana korupsi;

5. Melakukan monitor terhadap penyelenggaraan pemerintahan negara.

Dari pasal tersebut terlihat jelas bahwa pengisian Laporan Harta Kekayaan Penyelenggara Negara (LHKPN) ditujukan untuk mencegah terjadinya tindak pidana korupsi, yaitu bagian utama dari tugas pokok Komisi Pemberantasan Korupsi di poin 4, sebagaimana tertulis pada lembar pengantar Laporan Harta Kekayaan Penyelenggara Negara (LHKPN). Di dalam Laporan Harta Kekayaan Penyelenggara Negara (LHKPN) terdapat data-data yang bersifat rahasia dan kerahasiaan itu juga dijamin oleh undang-undang lain seperti Undang - Undang Kerahasiaan Bank yang diatur dalam Pasal 40 Undang-Undang Nomor 10 Tahun 1998 yang isinya: Ayat (1) Bank wajib merahasiakan keterangan mengenai nasabah penyimpan dan simpanannya, kecuali dalam hal sebagaimana dimaksud dalam Pasal 41, Pasal 41A, Pasal 42, Pasal 43, Pasal 44, dan Pasal 44A. Ayat (2) Ketentuan sebagaimana dimaksud dalam ayat (1) berlaku pula bagi pihak terafiliasi (termasuk Komisi Pemberantasan Korupsi).

\section{Kendala dan Solusi Pelaporan Harta Kekayaan Bagi Pejabat Negara}

Pelaksanaan pelaporan harta kekayaan pejabat negara sebagai upaya pencegahan tindak pidana korupsi pada Maret 2012 menjelaskan bahwa pelaksanaan LHKPN berjalan dengan baik meski tidak mungkin berjalan 100\%. LHKPN (Laporan Kekayaan Penyelenggara Negara) adalah daftar seluruh kekayaan Penyelenggara Negara yang dituangkan dalam formulir 
LHKPN yang ditetapkan oleh Komisi Pemberantasan Korupsi. ${ }^{14}$ Ada juga penyelenggara yang tidak taat dalam melaporkan harta kekayaannya. Sebagai contoh, Aryanto Sutadi (pensiunan Jenderal Polisi) yang masuk daftar 8 orang yang lolos seleksi panitia Seleksi Pimpinan KPK tahun 2011. Pada saat wawancara dengan DPR, Aryanto mengakui merekayasa LHKPN serta termasuk pejabat negara yang tidak taat melaporkan harta kekayaan. Pasal 20 Undang-Undang Nomor 28 Tahun 1999 yang menyatakan bahwa : "Setiap Pejabat negara yang melanggar ketentuan sebagaimana dimaksud dalam Pasal 5 angka 1,2,3,4,5, atau 6 dikenakan sanksi administratf sesuai dengan ketentuan peraturan perundang-undangan yang berlaku." Sedangkan kewajiban yang dimaksud dari pasal 5 ayat 3 adalah : "setiap pejabat negara berkewajiban untuk : melaporkan dan mengumumkan kekayaannya sebelum dan setelah menjabat" KPK yang mempunyai kewenangan mengenai LHKPN, hanya dapat memberikan masukan bagi atasan instansi/lembaga wajib LHKPN yang tidak taat tersebut untuk mendapat sanksi administrasif. Sanksi yang hanya administratif dan hanya dapat diberikan oleh instansi yang terkait merupakan sebuah hambatan bagi KPK, khususnya dalam pelaksanaan LHKPN. ${ }^{15}$

Dalam pelaporan harta kekayaan bagi pejabat negara pasti menimbulkan kendala. Sanksi administratif sejauh ini sudah dilaksanakan, yaitu dengan melakukan penelusuran asal muasal harta kekayaan pejabat negara, karena ditengarai jika hartanya meningkat meningkat tajam, ada indikasi melakukan tindak pidana korupsi.

Kewajiban dan sanksi tentang LHKPN dalam UU Nomor 28 Tahun 1999, sekilas memang tidak menunjukkan adanya permasalahan. Namun bila kita teliti lebih lanjut, bisa kita temukan sebuah permasalahan. Norma dalam undang-undang tersebut tidak tegas. Ketidaktegasan tersebut dalam Pasal 5 UU Nomor 28 Tahun 1999 yang hanya menggunakan norma kewajiban

\footnotetext{
${ }^{14}$ Wilson Gunawan Salim, Op.Cit, hal 48 “.

15 Miracle M. A. A. S. Sihombing, Laporan Kuliah Kerja Lapangan, Pelaksanaan Pelaporan Harta Kekayaan Pejabat Negara Sebagai Upaya Pencegahan Tindak Pidana Korupsi, Laporan KKL tidak diterbitkan, Malang, Fakultas Hukum Universitas Brawijaya,
} 2012, hal 34 . 
Penyelenggara Negara tanpa diimbangi dengan norma kewenangan lembaga pelaksananya. UU Nomor 28 Tahun 1999 telah menyembunyikan atau tidak menjelaskan lembaga yang berwenang memeriksa dan memastikan dilaporkan dan diumumkannya LHKPN, serta memberi sanksi bagi Penyelenggara Negara tersebut.

UU Nomor 30 Tahun 2002 tentang KPK, menjelaskan mengenai kewenangan KPK untuk melakukan pendaftaran dan pemeriksaan terhadap LHKPN tersebut sebagai salah satu upaya pencegahan korupsi. Namun tidak satupun pasal yang memberikan kewenangan bagi KPK untuk ikut menegakkan sanksi bagi penyelenggara Negara yang melanggar kewajibannya untuk melaporkan harta kekayaan. Bila ada yang melanggar kewajiban untuk melaporkan harta kekayaannya, maka KPK hanya dapat memberikan daftar kepatuhan yang berisi orang yang patuh dan yang tidak patuh LHKPN dalam suatu instansi kepada instansi yang berjatuhan untuk dijatuhi sanksi. Oleh sebab itu, diperlukan ketegasan mengenai kewenangan KPK dalam memberikan sanksi terhadap pejabat negara yang dengan sengaja tidak melaporkan harta kekayaannya agar sanksi pidana maupun sanksi administrtaif mampu memberikan efek jera terhadap oknum pejabat negara yang telah memalsukan pelaporan harta kekayaannnya.

Kendala yang dihadapi terkait pelaporan harta kekayaan oleh pejabat negara meliputi kurangnya sosialisasi ke instansi-instansi. Disamping itu semua pejabat wajib melaporkan harta kekayaanya secara berkala.

Solusinya berdasarkan penelitian, fasilitas atau sumberdaya-sumberdaya tersebut sudah cukup terpenuhi, namun berdasarkan hasil observasi yang dilakukan peneliti, mengingat banyak nya urusan yang menyangkut program eLHKPN menurut peneliti, admin instansi seharusnya jumlah nya lebih dari satu agar pekerjaan nya lebih efektif. Selain itu, sosialisasi secara kontinyu perlu dilaksanakan secara bertahap. 
e-ISSN : 2621-4105

\section{E. PENUTUP}

Pasal 5 ayat 3 UU Nomor 28 Tahun 1999 memberikan kewajiban bagi penyelenggara Negara untuk melaporkan dan mengumumkan kekayaannya. Kata "wajib" dalam pasal ini merupakan sebuah bentuk permintaan atau perintah bagi pihak yang terkait, dalam hal ini Penyelenggara Negara. Sehingga, dalam hal mekanisme LHKPN apabila tidak melaporkan kekayaannya termasuk suatu perbuatan yang tidak mentaati perintah/permintaan yang dilakukan menurut undang-undang. Kendala yang dihadapi terkait pelaporan harta kekayaan oleh pejabat negara meliputi kurangnya sosialisasi ke instansi-instansi.. Upaya pelaporan harta kekeyaan pejabat negara harus dilakukan sejak awal pejabat tersebut diberikan kewenangan pada jabatannya, sehingga dapat menjadi suatu kebiasaan yang positif dikalangan pemerintah. Pidana memanglah merupakan ultimum remidium namun pemberian sanksi pidana ini tujuannya bukanlah pembalasan atas tindak pidana yang dilakukan, melainkan untuk sebagai upaya pencegahan. Sehingga menurut penulis, sudah saatnya mengkaji pasal $20 \mathrm{UU}$ Nomor 28 Tahun 1999 dan melengakapinya dengan sanksi pidana, sehingga tujuan hukum yakni kemanfaatan dalam hal ini bermanfaat bagi upaya pencegahan tindak pidana korupsi dapat terwujud. Sanksi administratif yang ada dalam mekanisme LHKPN dianggap kurang berjalan maksimal dan terkesan percuma. Sehingga perlu diupayakan mengenai pentingnya sanksi yang lain yang dapat memberikan efek jera bagi pelaku, yakni dapat berupa sanksi pidana dalam pelaksanaan Laporan Harta Kekayaan Penyelenggara Negara.

\section{DAFTAR PUSTAKA}

\section{Buku}

Amirudin, "Pengantur Metode Penelitian Hukum", PT. Raja Grafindo Persada, Jakarta, 2004.

Burhan Ashofa, "Metode Penelitian Hukum", Rineka Cipta, Jakarta, 2001. Mukti Fajar ND dan Yulianto Achmad, "Dualisme Penelitian Hukum Normatif \& Empihs", Pustaka Pelajar, Yogyakarta, 2013. 
Rony Hanitijo Soemitro. "Metode Penelitian Hukum dan Jumitri", Ghalia Indonesia, Yogyakarta, 1988.

Soerjono Soekanto, "Pengantar Penelitian Hukum", Ul Press, Jakarta, 2005.

\section{Jurnal}

Anton Wibisono, "Determinan Intensi Pelaporan Pelanggaran: Studi Empiris Pada Direktorat Jenderal Kekayaan Negara", Jurnal Ekonomi dan Bisnis, 21(2) ,2018. DOI: 10.24914/jeb.v21i2.1985.

Ahmaf Fajri Kahar, "Pengampunan Pajak Terhadap Harta Kekayaan Hasil Tindak Pidana Pencucian Uang", Jurnal Education and Development Institut Pendidikan Tapanuli Selatan 8 (2), 2020. DOI:10.37081/ed.v8i2.

Aryas Adi Suyanto, "Komisi Pemberantasan Korupsi Sebagai Lembaga Rasuah dalam Pemberantasan Tindak Pidana Korupsi di Indonesia", Jurnal USM Law Review 1 (1), 2018. DOI: 10.26623/julr.v1i1.2231.

Heri Fasial Harahap, "Pengaruh Jalur Pelaporan dan Komitmen Religius Terhadap Niat Melakukan Whistleblowing: Sebuah Studi Eksperimen", JIA (Jurnal Ilmiah Akuntansi 5(1), 2020, DOI: 10.23887/jia.v5i1.24289.

Miracle M. A. A. S. Sihombing, "Laporan Kuliah Kerja Lapangan, Pelaksanaan Pelaporan Harta Kekayaan Pejabat Negara Sebagai Upaya Pencegahan Tindak Pidana Korupsi”, Laporan KKL tidak diterbitkan, Malang, Fakultas Hukum Universitas Brawijaya.

Wilson Gunawan Salim, "Kepastian Hukum Terhadap Tidak Dilaporkan Harta Kekayaan Penyelenggara Negara Dalam Penyeleksian Calon Pimpinan Komisi Pemberantasan Korupsi", Jurnal Corruptio Universitas Lampung 1 (1), 2020. DOI: 10.17081/ed.v209.

Yuniarty Veronika Ingnuan, Mohamad Lutfi, Pelaksanaan Peningkatan Kepatuhan Pelaporan Laporan Harta Kekayaan Penyelenggara Negara (LHKPN), Jurnal EKOBIS 8 (2), 2018. DOI : 10.37932/j.e.v8i2.43

Zainal Putra, "Sosialisasi Pelaporan Harta Kekayaan Penyelenggara Negara dengan Sistem E-LHKPN di Lingkungan Universitas Teuku Umar", Jurnal ADIMAS 4 (1), 2020. DOI : 10.24269/adi.v4i1.2301.

\section{Perundang-undangan}

Undang-Undang Dasar Negera Republik Indonesia 1945

Kitab Undang-Undang Hukum Pidana (KUHP)

Undang-Undang Nomor 28 Tahun 1999 Tentang Pejabat negara yang Bersih dan Bebas dari Korupsi, Kolusi, dan Nepotisme ;

Undang-Undang Nomor 36 Tahun 2008 Tentang Pajak Penghasilan. 